\title{
Distinctive Symptoms and Signs of Downy Mildew on Cold-Climate Wine Grape Cultivars
}

\author{
David S. Jones and Patricia S. McManus, ${ }^{\dagger}$ University of Wisconsin, Madison 53706
}

Accepted for publication 19 August 2017.

Downy mildew, caused by the oomycete pathogen Plasmopara viticola, is a major disease affecting grape production worldwide. While the symptoms and signs of downy mildew on European wine grapes (Vitis vinifera) are well documented (Ash 2000; Fenn et al. 2004; Gao et al. 2009; Kassemeyer et al. 2015; Wilcox and Wolf 2008), minimal information is available regarding the symptoms and signs on cold-hardy cultivars that are crosses of $V$. vinifera and Vitis species native to North America (e.g., V. riparia, V. rupestris, $V$. aestivalis, and V. labrusca). Referred to hereafter as "coldclimate cultivars," these hybrids have been released over the past two decades and form the basis of a burgeoning wine industry in the northern United States. Most research on downy mildew of grape has involved $V$. vinifera, and consequently, many images used for educational purposes illustrate "classic" symptoms and signs on highly susceptible cultivars of $V$. vinifera (Ash 2000; Fenn et al. 2004; Gao et al. 2009; Kassemeyer et al. 2015; Wilcox and Wolf 2008). However, we have observed that such images can be inconsistent with symptomology in the cold-climate grape hybrids, and there are differences in the symptoms and signs of downy mildew among coldclimate cultivars. These inconsistencies can result in incorrect diagnosis, which can lead to poor management decisions, including application of products that are not appropriate for the pathogen(s) present. Thus, the objective of the current guide is to describe downy mildew symptoms and signs on cold-climate cultivars, with special attention to features that are not documented in resources widely used for grape disease diagnosis. The images shown are representative of symptoms and signs observed over two years at two distinct locations. However, users of this guide should bear in mind that appearance of symptoms throughout the growing season may differ at other locations and under different environmental conditions.

Host(s): All cultivars of grapes in the species Vitis vinifera and Vitis intraspecific hybrid cultivars, including cold-climate cultivars, as well as other Vitis species including V. riparia, V. rupestris, V. aestivalis, V. labrusca, and V. cinerea (https://nt.ars-grin.gov/fungaldatabases; Ash 2000).

Disease: Downy mildew (Plasmopara viticola [Berk. \& M.A. Curtis] Berl. \& De Toni, Sylloge Fungorum 7:239 [1888]).

Taxonomy: Domain Eukaryota; kingdom Chromista; superphylum Heterokonta; class Oomycota; subclass Oomycetes; order Peronosporales; family Peronosporaceae; genus Plasmopara;

${ }^{\dagger}$ Corresponding author: P. S. McManus; E-mail: pmcmanus@wisc.edu

(C) 2017 The American Phytopathological Society species P. viticola (www.mycobank.org; https://nt.ars-grin.gov/ fungaldatabases).

Plasmopara viticola has been renamed several times as understanding of its distinction as an oomycete as well as its distinction from the genus Phytopthora has expanded. Originally named Botrytis viticola (Berk. \& M.A. Curtis) in 1848, it was subsequently renamed Peronospora viticola ([Berk. \& M.A. Curtis] Casp.) in 1885, and then renamed again to Phytopthora viticola (Berk. \& M.A. Curtis [W. Reichelt]) in 1887. It was renamed to Rhysotheca viticola Berk. \& M.A. Curtis [G.W. Wilson]) in 1907 and renamed again to Plasmopara amurensis (Prots.) in 1946. It was ultimately named Plasmopara viticola (Berk. \& M.A. Curtis) Berl. \& De Toni, a name which was originally given in 1888. Current taxonomic information is available at the Systematic Mycology and Microbiology Laboratory, USDA-ARS (https://nt.ars-grin.gov/fungaldatabases), and Mycobank (www.mycobank.org).

\section{Symptoms and Signs}

The descriptions of symptoms and signs in this section are based on sources often used by extension educators, crop consultants, and growers when identifying diseases of grapes (Ash 2000; Fenn et al. 2004; Gao et al. 2009; Kassemeyer et al. 2015; Wilcox and Wolf 2008). Later in this guide, we illustrate cases in which symptoms and signs on cold-climate cultivars diverge from classic symptoms described in current literature. Downy mildew can affect all green parts of the grape vine. Damage is typical on leaves, inflorescences, and young berries. Leaf symptoms first appear on the adaxial surface as roughly circular, shiny, bruised areas slightly darker than surrounding healthy tissue. These spots rapidly turn yellow to brownish yellow, a symptom often referred to as an "oil spot." The tissue in these spots later becomes necrotic, turning reddish brown, and the lesion takes on a more angular appearance. Lesions are often delimited by veins, and lesions appearing late in the season are sometimes smaller than those initiated earlier. Sporulation occurs on the abaxial surface of lesions and appears as a dense, white, cottony (or as the disease name suggests, downy) mass. Sporulation of $P$. viticola on leaves is exclusive to the abaxial surface, as this pathogen relies on the natural openings created by stomata as an exit point for sporangiophores. This cottony mass consists of sporangia born on sporangiophores. Leaves with many lesions on the adaxial surface may fall prematurely. If shoot tips and rachises are infected while they are rapidly growing, they can curl into a "shepherd's crook." Sporulation on petioles, tendrils, and inflorescences is similar to that observed on leaves, and is especially prominent when conditions are damp (Kassemeyer et al. 2015).

Young berries on most widely grown $V$. vinifera cultivars are highly susceptible to downy mildew (Fenn et al. 2004; Gao et al. 2009; Wilcox and Wolf 2008). Berries infected at an early developmental stage display a cottony mass of sporangia on the berry 
surface. Berries become impervious to direct infection later in development as lenticels replace stomata, but pedicels can remain susceptible for several weeks following bloom (Kennelly et al. 2005; Wilcox and Wolf 2008). Berries can become infected indirectly as the pathogen grows from infected pedicels. Berries of white-fruited cultivars infected in this way turn a leathery brown color, while berries of red-fruited cultivars turn pinkish-red.

\section{Host Range}

Plasmopara viticola infects members of the genus Vitis and other members of the Vitaceae (https://nt.ars-grin.gov/fungaldatabases).

\section{Geographic Distribution}

Plasmopara viticola is endemic to the wild Vitis species of North America. It was accidentally introduced to Europe in the late 1800s, and is now present in many major grape-producing regions worldwide (https://nt.ars-grin.gov/fungaldatabases; Gessler et al. 2011).

\section{New Documentation of Grape Downy Mildew on Cold-climate Cultivars}

Methods and observations. Observations were conducted in 2015 and 2016 at the West Madison Agricultural Research Station in Verona, WI (WMARS, USDA zone 5a), and the Peninsular Agricultural Research Station in Sturgeon Bay, WI (PARS, USDA zone $5 \mathrm{~b}$ ). These two zones represent significant regions for coldclimate viticulture in Wisconsin and the northern United States. Downy mildew had been reported previously at WMARS and PARS, and therefore no inoculum was added artificially. The following cultivars were observed in both years at both locations in vineyard blocks established in 2012: Brianna, Frontenac, Frontenac gris, La Crescent, La Crosse, Marquette, St. Croix, and Valiant. Valiant was previously reported to be highly susceptible to downy mildew (Smiley et al. 2015) and was included in this study as a disease indicator. Additionally, cultivars observed at PARS in 2016 in a vineyard block established in 2008 included: Brianna, Frontenac, Frontenac gris, La Crescent, La Crosse, Léon Millot, Maréchal Foch, Marquette, and Petite Pearl. Collectively, the cultivars observed in this study account for over $80 \%$ of red-fruited and over $50 \%$ of whitefruited cold-climate grape acreage in the northern United States (Gartner 2016). No fungicides were applied to vines in years in which they were observed for downy mildew. Aside from the absence of fungicide applications, the vineyards were managed according to conventional practices (Bordelon et al. 2017). Winter pruning reduced the number of buds to three buds per established spur, and shoots were thinned in the spring to three per established spur. Vines were hedged as needed, sucker sprouts were removed, and bird netting was used to prevent damage during berry ripening. Insecticides were applied as needed at both sites to control grape phylloxera, grape berry moth, and Japanese beetle. All vines were trained in the vertical shoot positioning system at the time of establishment.

In 2015, PARS 1 accumulated $474 \mathrm{~mm}$ of rainfall in 49 rain events between 15 May and 1 October, the period during which vines were observed for downy mildew. WMARS accumulated $470 \mathrm{~mm}$ of rainfall in 47 rain events between 8 May and 10 September, the period during which vines were observed for downy mildew. Both sites received at least one rain event every 11 days during the 2015 growing season. In 2016, PARS 1 and PARS 2 accumulated $462 \mathrm{~mm}$ of rainfall in 55 rain events between 18 May and 23 September, the period during which vines were observed for downy mildew. WMARS accumulated $620 \mathrm{~mm}$ of rainfall in 50 rain events between 5 May and 14 September, the period during which vines were observed for downy mildew. Both sites received at least one rain event every 7 days during the 2016 growing season.

Beginning when leaves unfolded in the spring, vineyards were scouted for downy mildew symptoms and signs once per 2-week period by the same researcher for the duration of the growing season, ending 2 weeks after harvest. Vines were scouted between $0700 \mathrm{~h}$ to $1600 \mathrm{~h}$, and because cultivars were replicated four to five times and arranged in a randomized complete block design, replicates of each cultivar were observed over that time period. The entire plant was observed and a distinction between symptoms on foliage and symptoms on fruit clusters was made. Symptoms observed on either rachises or grape berries were categorized as fruit cluster disease, while symptoms on leaves and stems were categorized as foliar disease. The following cultivars developed downy mildew symptoms that were generally consistent with descriptions of symptoms and signs of foliar downy mildew in existing literature (Ash 2000; Fenn et al. 2004; Gao et al. 2009; Kassemeyer et al. 2015; Wilcox and Wolf 2008): Brianna, La Crescent, St. Croix, and Valiant. Brianna also developed unusual symptoms, as described below. Only Valiant developed downy mildew symptoms on fruit clusters that were consistent with descriptions of symptoms and signs in existing literature. Key additions to existing documentation of the signs and symptoms of grape downy mildew on cold-climate grape cultivars are as follows.

Minimal or no sporulation on abaxial leaf surface. Sporulation is frequently absent on the abaxial surface of downy mildew lesions on Frontenac, Frontenac gris, Marquette, and Petite Pearl (Figs. 1 and 2). While sporulation can be observed when leaves are incubated
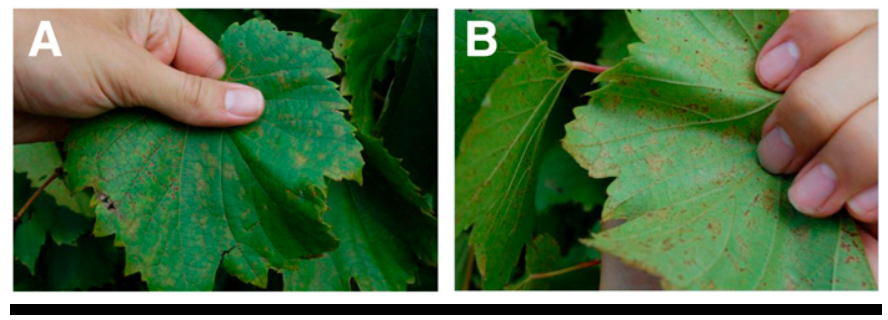

\section{FIGURE 1}

Oil spots on the adaxial surface of a Frontenac leaf $(\mathbf{A})$, and abaxial surface of the same leaf (B). Frontenac, Frontenac gris, Marquette, and Petite Pearl are prone to downy mildew on old foliage in the fruiting zone late in the season. Look for oil spotting (A) on the oldest leaves, near the fruit. Sporulation on Frontenac, Frontenac gris, Marquette, and Petite Pearl can appear more sparse than on other cultivars (if present at all), with undersides of oil spots often being dark (B). A hand lens is often necessary to observe sporulation, and lesions often lack sporangia altogether as the few sporangia produced are quickly dispersed.
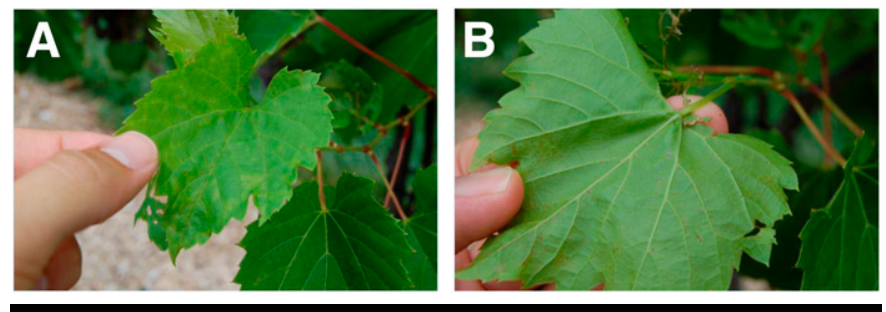

\section{FIGURE 2}

Faint oil spots on the adaxial surface of a Frontenac leaf at the tip of an axillary shoot in late August (A), and abaxial surface of the same leaf (B). While oil spots can be common on the adaxial surfaces of leaves (A), sporulation on the abaxial surfaces of these lesions can be difficult to find and is not visible in B. Sporulation can be found briefly after rain events or particularly humid nights, but it quickly disappears when humidity drops. 
in a moist chamber for 1 to 3 days, the frequent absence of sporulation underneath oil-spot lesions in the field can make diagnosis difficult, particularly as these lesions become necrotic as the season progresses. Oil spots can be observed on both older foliage and younger tip growth as the season progresses (Figs. 1 and 2).

Variant adaxial lesion morphology. La Crosse, a popular coldclimate cultivar with severe susceptibility to foliar downy mildew, can develop necrotic lesions without displaying an "oil spot" phase (Fig. 3). These necrotic lesions were the first symptom of downy mildew that was recorded on this cultivar during both growing seasons, and were first observed on 5 June at WMARS and 25 June at PARS 1 in 2015 and 14 June at WMARS and 14 July at PARS 1 and PARS 2 in 2016. Light sporulation can sometimes be observed on the abaxial surface of these lesions, but as with Frontenac, Frontenac gris, Marquette, and Petite Pearl, it is difficult to observe in the field with the naked eye (Fig. 3B). While oil spots can sometimes be observed in this cultivar, symptoms on La Crosse are predominantly the necrotic lesions with sparse sporulation described above. In addition to the notable difference in the appearance of individual lesions, La Crosse downy mildew lesions frequently exhibit "vein tracking" (Fig. 4),


\section{FIGURE 3}

Early symptoms of downy mildew on the adaxial surface of a La Crosse leaf (A) appear dry and brown, as opposed to the more typical yellow "oil spot" type of lesion. Sporulation on the abaxial surface of the same leaf (B) is limited to the underside of the brown, necrotic lesion.
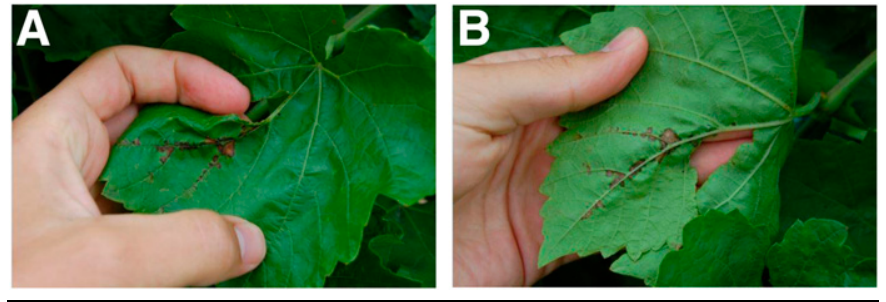

\section{FIGURE 4}

Downy mildew lesions on La Crosse leaves can exhibit vein tracking (A). Sporulation on the abaxial surface of La Crosse leaves (B) is minimal.



\section{FIGURE 5}

Downy mildew lesions on older leaves of Brianna are distinctive. Lesions on the adaxial surface $(\mathbf{A})$ are small and dark, turning brown or black rather than having a prolonged yellow/dirty yellow "oil spot" phase that is seen in other cultivars. Sporulation on the abaxial surface of the same leaf (B) is patchy and limited to the older, darker lesions. a symptom not seen on other cold-climate cultivars. The cultivar Brianna often exhibits lesions similar to those described for La Crosse on the adaxial surface of older leaves near the cordon (Fig. 5). On such lesions, sporulation on undersides of leaves is sparse (Fig. 5B).

The cultivars Léon Millot, Maréchal Foch, and Petite Pearl frequently display an additional atypical downy mildew lesion symptom. Rather than a defined necrotic lesion or oil spot, infected leaves of these cultivars sometimes develop an undefined, dark olive to black, spotted region on the adaxial surface (Fig. $6 \mathrm{~A}$ and B). The abaxial surface displays sporulation that is not necessarily associated with an oil spot or lesion the adaxial surface (Fig. $6 \mathrm{C}$ and D). While sporulation can be observed, the frequent absence of prominent yellow oil spots makes downy mildew on these three cultivars distinctive.

Absence of symptoms and signs on fruit clusters. Both the foliage and fruit of $V$. vinifera are generally susceptible to downy mildew (Ash 2000; Fenn et al. 2004; Gao et al. 2009; Kassemeyer et al. 2015; Wilcox and Wolf 2008). However, this is not the case for most coldclimate cultivars we observed. Brianna, Frontenac, Frontenac gris,
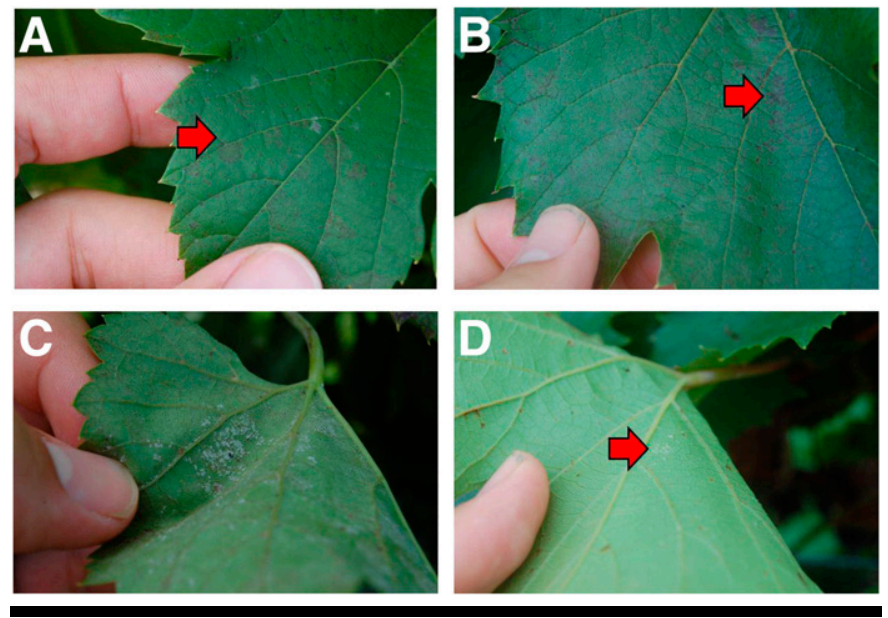

\section{FIGURE 6}

Downy mildew lesions on the adaxial surfaces of Léon Millot (A) and Petite Pearl (B) leaves, indicated by arrows, can be faint and black-brown, particularly near the end of the growing season, on old, fully expanded leaves within the fruiting canopy. Sporulation on abaxial surfaces of the leaves shown in $A$ and $B$ is shown in C (Léon Millot) and D (Petite Pearl), respectively.

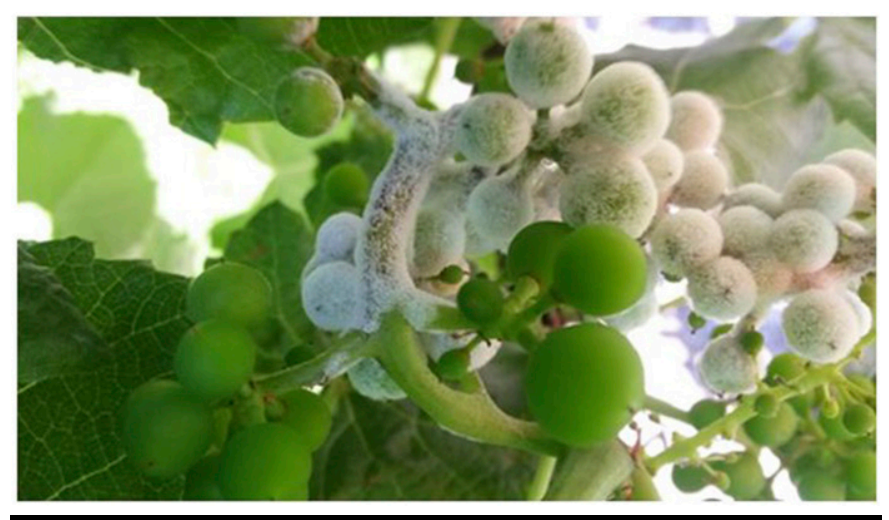

\section{FIGURE 7}

Valiant clusters are highly susceptible to downy mildew, displaying symptoms and signs early in the season shortly after fruit set. Downy mildew can result in complete loss if not managed, but among the cultivars we observed, this was unique to Valiant. 


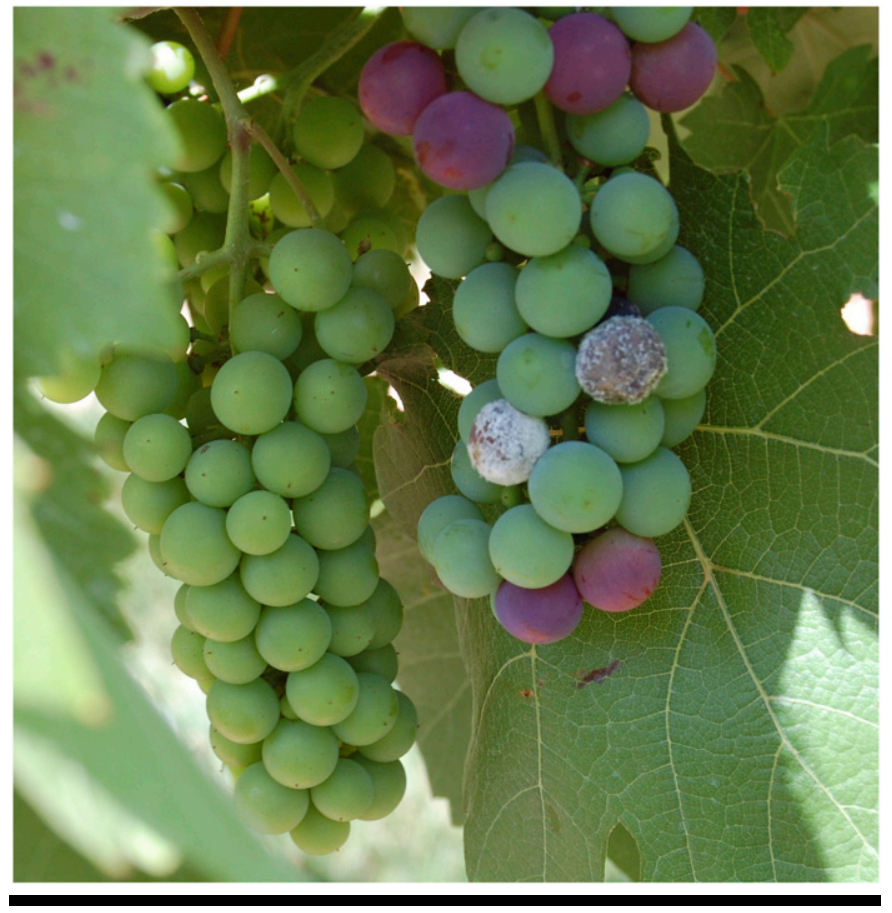

FIGURE 8

Healthy Marquette cluster (left) next to Valiant cluster (right) with prematurely red and sporulating berries indicative of downy mildew. Even in the presence of heavy sporulation on both fruit and foliage of Valiant, fruits of all other cultivars studied in this work remained healthy.

La Crosse, La Crescent, Léon Millot, Maréchal Foch, Marquette, Petite Pearl, St. Croix, and Valiant display a wide range of foliar susceptibility to disease (Jones and McManus 2017), but of these cultivars, only Valiant is susceptible to visible disease on fruit (Figs. 7 and 8), with $>80 \%$ of clusters diseased in both 2015 and 2016 (Jones and McManus 2017). No downy mildew on clusters (i.e., berries or rachises) was recorded in any trial in 2015 or 2016 on any other cultivar in spite of conducive weather conditions and profuse sporulation on foliage of susceptible cultivars.

\section{Summary}

Several cold-climate wine grape cultivars frequently display variant downy mildew lesion shapes and colors, patterns of sporulation, and distribution of lesions on leaf surfaces. Additionally, the majority of these cultivars are resistant to symptoms and signs on fruit throughout the growing season, a feature rarely reported in existing diagnostic literature. This new information will assist in identification of downy mildew symptoms and signs on cold-climate cultivars and will help growers reduce the risk of misdiagnosis and incorrect fungicide application.

\section{Acknowledgments}

We thank J. Hedtcke and M. Stasiak and their teams at WMARS and PARS, respectively, as well as A. Cramer and M. Hughan for help in the field. This work was funded by the USDA Specialty Crops Research Initiative Northern Grapes Project (award no. 2011-51181-30850) and USDA Sustainable Agriculture Research and Education (project no. GNC15-210).

\section{Literature Cited}

Ash, G. 2000. Downy mildew of grape. Plant Health Instructor. American Phytopathological Society, St. Paul, MN. doi:10.1094/PHI-I-2000-1112-01

Bordelon, B., Beckerman, J., Ward Gautier, N., Strang, J., and Geudot, C. 2017. Grape spray schedule. Pages 81-101 in: Midwest Fruit Pest Management Guide. Coop. Ext. Bull 465. Purdue Univ., West Lafayette, IN.

Fenn, P., Vann, S. R., Gleason, M., Tisserat, N. A., Ellis, M., Pecknold, P. C., Babadoost, M., Hartman, J. R., Moore, J. M., Watkins, J., and McManus, P. 2004. Downy mildew. Pages 131-133 in: Midwest Small Fruit Pest Management Handbook. M. A. Ellis, C. Welty, R. C. Funt, D. Doohan, R. N. Williams, M. Brown, and B. Bordelon, eds. Ohio State Univ. Ext., Columbus, OH.

Gao, G., Becker, R., Brown, M., Ellis, M., Prochaska, S., Welty, C., and Williams, R. 2009. Downy mildew. Pages 130-132 in: Midwest Home Fruit Production Guide: Cultural Practices and Pest Management. Coop. Ex. Bull. 940. Ohio State Univ. Ext., Columbus, $\mathrm{OH}$.

Gartner, B. 2016. Northern grapes project surveys show growth. North. Grapes News. 5:8-10.

Gessler, C., Pertot, I., and Perazzolli, M. 2011. Plasmopara viticola: A review of knowledge on downy mildew of grapevine and effective disease management. Phytopathol. Mediterr. 50:3-44. http://www.fupress.net/index.php/pm/ article/view/9360/8659

Jones, D. S., and McManus, P. S. 2017. Susceptibility of cold-climate wine grape cultivars to downy mildew, powdery mildew, and black rot. Plant Dis. 101: 1077-1085.

Kassemeyer, H. H., Gadoury, D. M., Hill, G., and Wilcox, W. F. 2015. Downy mildew. Pages 46-52 in: Compendium of Grape Diseases, Disorders, and Pests, 2nd Ed., W. F. Wilcox, W. D. Gubler, and J. K. Uyemoto, eds. American Phytopathological Society, St. Paul, MN.

Kennelly, M. M., Gadoury, D. M., Wilcox, W. F., Magarey, P. A., and Seem, R. C. 2005. Seasonal development of ontogenic resistance to downy mildew in grape berries and rachises. Phytopathology 95:1445-1452.

Smiley, L.A., Domoto, P., and Nonnecke, G. 2015. Cold Climate Cultivars: A Review of Cold Climate Grape Cultivars. Ext. and Outreach Bull. 3040-73, Iowa State Univ., Ames, IA.

Wilcox, W. F., and Wolf, T. K. 2008. Downy mildew. Pages 222-224 in: Wine Grape Production Guide for Eastern North America. T. K. Wolf, ed. Natur. Resource, Agric., and Eng. Serv. (NRAES) Coop. Ext., Ithaca, NY. 